\title{
INFLUENCE OF THE SUBSTRATES ON THE PRODUCTIVITY AND THE NUTRITIONAL VALUE OF HOUSEFLY LARVAE (Musca domesticus) MEAL FOR BROILERS NUTRITION
}

\author{
Marie Noël Bertine NOUMBISSI ${ }^{\circledR 凶}$, Ruben Ngouana TADJONG², Frank Maël TCHAKOUNTE ${ }^{1}$, Ydosile KANA $^{1}$, \\ Reine KEYI ${ }^{1}$, and Jean Raphaël KANA ${ }^{1}$
}

${ }_{1}^{1}$ Animal Production and Nutrition Research Unit, Faculty of Agronomy and Agricultural Sciences, University of Dschang. PO Box: 188 Dschang, Cameroon 2Laboratory of Aquatic Resources, Department of Aquaculture, Institute of Fisheries and Aquatic Sciences, University of Douala, Douala, Cameroon

Email: dadamanol@yahoo.fr; (DORCID: 0000-0003-0767-4115

Supporting Information

ABSTRACT: The present study was assigned to assess the production and nutritional value of maggots (housefly larvae, Musca domestica) meals produced in chicken droppings and pig slurry as substrates and their effects on growth performance and serological parameters of broiler chicks at the starter phase. A control ration without animal meal (R0) was compared to three other rations containing respectively $5 \%$ fishmeal (FM), blood meal (BM) and maggots (MA). The rations were randomly distributed to 4 groups (T0, FM, BM, and MA) of 56 chicks each. Slurry supplemented with bovine blood has been shown to be more productive than other substrates, with a maximum production of $246.75 \mathrm{~g}$ per $2 \mathrm{~kg}$ of substrate after five days of incubation. The highest average temperature $\left(28.28 \pm 3.43^{\circ} \mathrm{C}\right)$ was recorded in chicken droppings around 12 hours of the day. The pupae appear before the 10th day and breeding was no longer productive after the $15^{\text {th }}$ day, both in hen droppings and in pig manure supplemented or not with blood. The humidity and temperature variations in the two substrates did not have any noticeable effects on the production and chemical composition of the maggots. Proximate analysis of maggot flour revealed a high content of protein (41-57\%), ash (7.31-8.26\%) and minerals such as phosphorus (5.25-5.55\%), calcium (1.92-3.92\%) and magnesium (7.04-7.92\%). The growth performance and development of regulatory organs and digestive organs such as liver, kidneys, intestine, and bursa of Fabricius of the chicks were not significantly affected by the dietary treatments. In conclusion, the production and nutritional value of maggots depend on the type and composition of the substrate and can be safely use as proteins sources in broilers at the starter phase of production.

Keywords: Animal manure, Broiler chicken, Fish meal, Maggot meal, Ration.

\section{INTRODUCTION}

One of the main solutions for the sustainability of the family animal production in Africa is the valorization of nonconventional locally available feed resources that are economically more profitable in animal feed formulation. In family poultry nutrition, the efforts are being made to promote new local sources of protein, such as the meal of insects, cockroaches, termites, grasshoppers, earthworms and maggots (Mensah et al., 2007; Tshinyama, 2009; Ndadi, 2010; Bouafou et al., 2011; Finke, 2013; De Smet et al., 2018).

Maggots are produced in household waste (Bouafou et al., 2008; Diener et al., 2009; Beskin et al., 2018), brewery dregs (Hardouin et al., 2000), animal droppings and the rumen contents of ruminants (Akilimali et al, 2019; Balengola, 2012). Maggot meal is rich in fat, protein and potentially essential amino acids (Hatab et al., 2020). They are used as food for animals, especially fish and local poultry (Mensah and Ekue, 2002; Biasato et al., 2019). Its nutritional value is broadly comparable to that of meat, fish, soybean and cotton meal which are conventionally used in livestock feed (BarraganFonseca et al., 2018). In terms of economic benefits, Téguia et al. (2002) and Hardouin and Mahoux (2003) reported that the substitution of fishmeal by maggot meal reduced the cost of fish production by 18 to $20 \%$. The use of this flour could offer a great opportunity for the development of poultry production in the tropics where maggots can be easily produced throughout the year and at low cost.

To safely prescribe maggot meal in animal feed, further investigation is necessary as maggots produced in animal droppings could be a source of transmission of fecal bacteria to farm animals (Charlton et al., 2015; De Smet et al., 2018). The study of the plasma parameters of growing rats fed on dried maggot meal-based diet did not revealed any abnormalities (Bouafou et al., 2011). However, the biometrics of their kidneys and livers revealed changes in weight, with their kidneys losing weight of around $6.6 \%$ and their livers increasing by $10.60 \%$ suggesting to pay more attention on the potential toxicity of the maggot meal produced in animal droppings to feed another animals. The main objective of this study was to promote the usage of locally available and less expensive protein resources (such as larvae meal) of animal origin in farm animal production. 


\section{MATERIALS AND METHODS}

\section{Ethical approval}

The present study has been performed in agreement with the guidelines of the ethical standards from the 1964 Helsinki declaration and latterly amendment approval code \#CU/11/F/34/19\#.

\section{Study area}

The present study was carried out at the Teaching and Research Farm (FAR) of the University of Dschang, located in

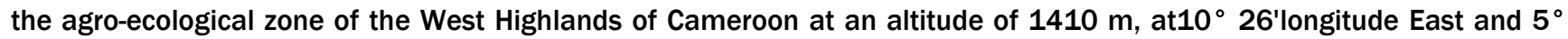
$26^{\prime}$ latitude North. The area receives between 1,500 and $2,000 \mathrm{~mm}$ of rainfall per year, with temperatures ranging from 10 to $25^{\circ} \mathrm{C}$. The climate is equatorial of Cameroonian type, with a dry season ranging from mid-November to mid-March and the rainy season from mid-March to mid-November. The average annual insulation is 1873 hours and the average relative humidity is $76.8 \%$.

\section{Maggot production}

The organic substrates used to produce the maggots consisted of chicken droppings and pig slurry. The fresh chicken droppings were collected from the henhouses at the Teaching and Research Farm of the University of Dschang on the ground under batteries of broiler cages. The pig slurry was collected at the piggery of the same farm, previously cleaned the day before. The blood of freshly slaughtered beef, used to attract flies, was collected at the municipal slaughterhouse of Dschang of Cameroon.

The production of the maggots was carried out in the plastic colanders inside which were introduced $2 \mathrm{~kg}$ of substrates (chicken droppings or pig slurry) enriched or not with $100 \mathrm{~g}$ of fresh beef blood. The colander was placed on a basin intended to collect the maggots which passed through the mesh. The breeding was conducted in an enclosure covered with transparent paper where flies could enter and exit freely (Figure 1). The entire device was stored in the open air and the smell of the substrate attracted flies that came to lay freely in the shelter from hash weather. The experimental design consisted of 4 treatments (chicken droppings, chicken droppings enriched with fresh blood, pig slurry and pig slurry enriched with fresh blood) replicated 4 times.

The temperature of the substrate was taken every day at 8a.m. and 12a.m. using a thermometer (Strengthened 76 $\mathrm{mm}$ immersion, ZEAL Made in England). The maggots were harvested in a series of 4 basins per treatment on the 5th, 10th and 15th day after sowing. During harvesting, the device was placed under the sun, and the maggots, fleeing the heat of the sun, fell into the collecting vessel. The harvested maggots were weighed fresh and oven dried at $70^{\circ} \mathrm{C}$ for at least 24 hours and then reweighed. The flours obtained were then mixed and incorporated into the feed of the chicks as a source of protein. The proximate analysis of maggots was carried out for protein, ash and mineral content (AOAC, 1990).

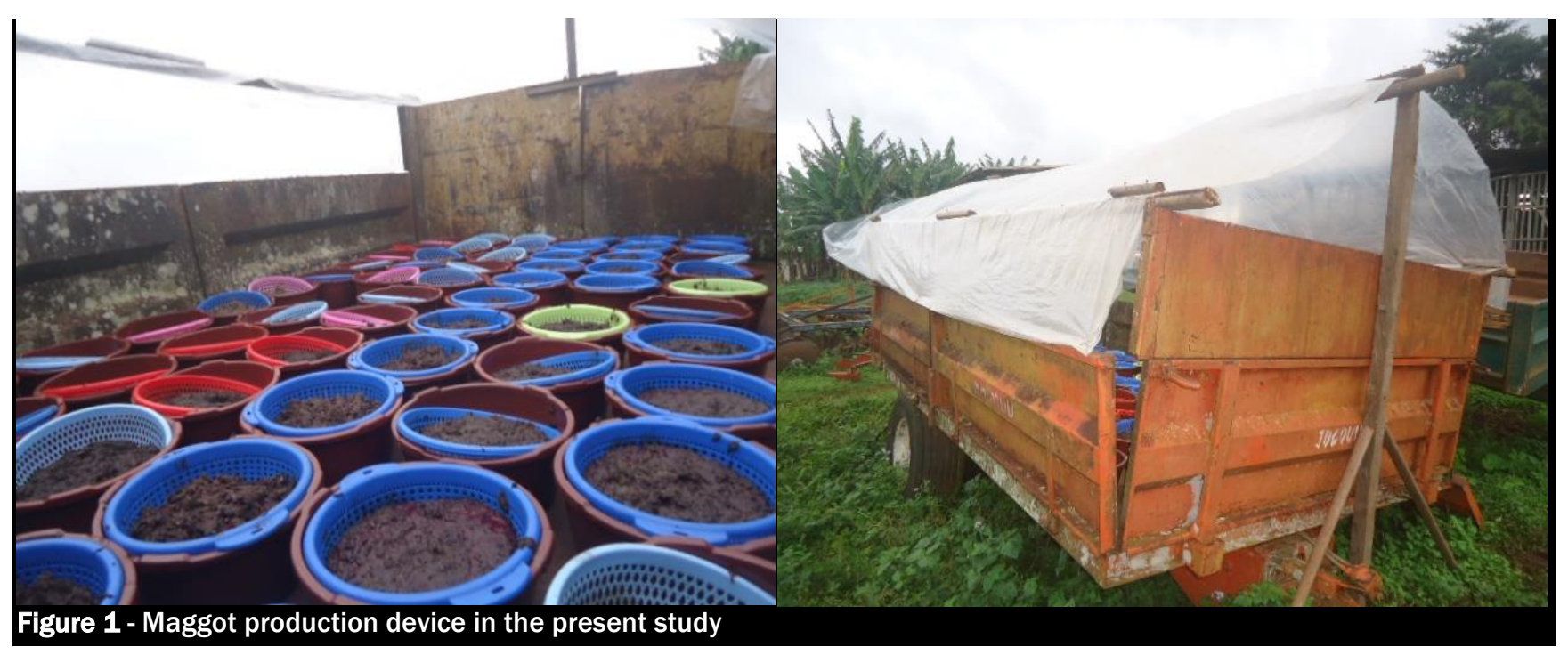

\section{Experimental chicks}

In the present study, 224 day-old Cobb 500 strain chicks with average mean weight $38.91 \mathrm{~g}$ were randomly assigned to 16 experimental units of 14 chicks and litter brooded for 4 weeks. The chicks were vaccinated against infectious bronchitis $\left(\mathrm{H} 120^{\circledR}\right)$, Newcastle disease (Hitchner $\mathrm{B} 1^{\circledR}$ ) on the $7^{\text {th }}$ and $18^{\text {th }}$ day, and against Gumboro disease (IBA Gumboro ${ }^{\circledR}$ ) on the $10^{\text {th }}$ day. An anti-stress (Tetracoli ${ }^{\circledR}$ ) was administrated to the chicks via drinking water after vaccinations. An anticoccidial $\left(\right.$ Vetacox ${ }^{\circledR}$ ) and vitamins $\left(\right.$ Amintotal ${ }^{\circledR}$ ) were administrated to the chicks via drinking water during 3 days each week. 


\section{Experimental diets}

Fish meal, blood meal and other ingredients were purchased from the market in the town of Dschang. Four experimental rations were formulated (Table 1) with the control ration (T0) free from ingredient of animal origin. The rations $\mathrm{FM}, \mathrm{BM}$, and MA contained fishmeal, blood, and maggots respectively. Each experimental ration was assigned, at random, to 4 experimental units in a completely randomized design replicated 4 times. Chicks were fed ad libitum throughout the trial period.

\section{Table 1 - Composition of experimental diets}

\begin{tabular}{|c|c|c|c|c|}
\hline Ingredients & TO & FM & BM & MA \\
\hline Maize & 54 & 54 & 54 & 54 \\
\hline Wheat bran & 6.5 & 7.5 & 11 & 6 \\
\hline Soybean meal & 25 & 21.5 & 18 & 21 \\
\hline Cotton seed meal & 5.5 & 5.5 & 5.00 & 7 \\
\hline Fishmeal & 0 & 5 & 0 & 0 \\
\hline Blood meal & 0 & 0 & 5 & 0 \\
\hline Maggot meal & 0 & 0 & 0 & 5 \\
\hline Bone meal & 1 & 1 & 1 & 0 \\
\hline Seashell & 1 & 1 & 1 & 0 \\
\hline Premix 5\% * & 5 & 5 & 5 & 5 \\
\hline Total & 100 & 100 & 100 & 100 \\
\hline \multicolumn{5}{|l|}{ Calculated chemical composition } \\
\hline Crude proteins $(\%)$ & 23.01 & 24.72 & 23.11 & 22.59 \\
\hline Metabolizable energy (kcal/kg) & $2,878.31$ & $2,896.21$ & $2,949.69$ & $2,888.76$ \\
\hline Calcium (\%) & 1.12 & 1.43 & 1.12 & 1.33 \\
\hline Available phosphorus (\%) & 0.49 & 0.65 & 0.51 & 0.6 \\
\hline Lysine (\%) & 1.29 & 1.38 & 1.42 & 1.15 \\
\hline Methionine (\%) & 0.43 & 0.48 & 0.42 & 0.40 \\
\hline Price of feed (fcfa/kg) & 247 & 240 & 230 & 228 \\
\hline
\end{tabular}

\section{Data collection}

Feed intake and live body weight gain were recorded weekly. At the beginning of the trial and every 7 days thereafter, the birds in each experimental unit were individually weighed and the weekly weight gain was calculated as the difference between 2 consecutives averages weekly weights. The feed conversion ratio was calculated as the ratio of the feed consumed during the week on the weekly weight gain. At the 28 days old, 08 chicks per treatment group were taken at random, fasted for $\mathbf{2 4}$ hours, and weighed, bled, scalded, plucked and eviscerated for carcass evaluation. The relative weight of kidneys, liver, intestine and bursa of Fabricius was calculated [(organ weight / fasting animal body weight) $x$ 100]. Intestine length (from duodenal loop to the cloaca) was measured and its density (intestine weight / intestine length) calculated.

The price per kilogram of the feed was evaluated based on the ingredient prices on the local market at the study period. The cost of production of kilogram of live weight of the chicken was estimated by multiplying the cost of kilogram of feed by the feed conversion ratio.

\section{Statistical analysis}

The collected data were subjected to one-way analysis of variance (ANOVA) for the effects of the substrate type, moisture content and temperature on larvae growth, and nutritive value of maggots produced on chick's growth performance. When there were significant differences between treatments groups, the Waller Duncan multiple ranged test was applied to separate means, and difference were considered significant at $p<0.05$. The statistical software SPSS 20.0 (Statistical Package of Social Sciences) was used for the analyses.

\section{RESULTS}

\section{Variation of temperature and water content of substrate}

Table 2 summarizes the changes in water content, temperature of chickens droppings and pig slurry during incubation and growth of maggots. Regardless of the type of substrate, the highest temperature was recorded at 12 a.m. as the heat increases during the day. When considering the pig slurry and chicken droppings separately, the statistical analysis revealed no significant difference $(P>0.05)$ at 8 a.m. and 12 a.m., between the substrate without blood and substrates enriched with blood. When considering the types of substrate separately, the analysis of variance revealed a significant difference $(P<0.05)$ between the slurry containing blood and the same substrate without blood, for the water content. When comparing the two types of substrate, it appears that the water content was higher $(P<0.05)$ in the pig slurry. 


\section{Maggot production as affected by the type of substrate}

From Table 3 which summarizes the production of maggots as a function of the type of substrate, it appears that the highest production was recorded on the $5^{\text {th }}$ day with the pig slurry enriched or not with blood. On the $10^{\text {th }}$ day, production was higher with chicken droppings. Overall, it is obvious that the production is greater when blood is used as fly bait regardless of the substrate considered. When considering the pig slurry or chicken droppings separately, the analysis of variance revealed no significant difference $(P>0.05)$ on the $5^{\text {th }}$ and $10^{\text {th }}$ day of incubation between the substrate without blood and the one enriched with the blood.

\section{Nutritional value of maggots as affected by the substrate}

Table 4 summarizes the variation of the nutritional value of maggots as affected by substrate. Maggots produced in droppings and slurry were comparable for the content of ash, potassium, sodium, phosphorus and magnesium. The iron and calcium contents are lower in the maggots produced respectively in the slurry enriched or not with bovine blood. The enrichment of chicken droppings with blood induced a substantial increase in the protein content of maggots, while the opposite effect was recorded with pig slurry enriched with blood. Overall, maggot meal is an important source of animal protein $(41-57 \%)$ for farm animals.

\section{Growth performance and cost of production of broiler chicks}

Results in Table 5 shows that with the exception of feed intake, all other growth parameters studied were significantly affected $(P<0.05)$ by the treatments. Overall, fishmeal induced the highest live weight $(935.90 \mathrm{~g})$ and feed conversion ratio (1.64) of all the treatments groups. However, these performances were statistically comparable $(P>0.05)$ to the performances of the chicks fed on maggot meal (895.97 $\mathrm{g}$ and 1.72 respectively). Although not significant, chicks fed on maggot meal recorded more weight gain $(857.06 \mathrm{~g})$ than chicks fed on blood meal (836.73 g). Compared to the control ration (441.47 FCFA), the production cost of a $\mathrm{kg}$ of live weight of the chick was lower with fishmeal (393.95 FCFA), blood meal (407.05 FCFA) and maggot meal (409.98 CFA).

\section{Development of regulatory and digestive organs}

The effects of different treatments on the development of regulatory and digestive organs of the chicks are summarized in Table 6. ANOVA did not reveal any significant difference $(P>0.05)$ between treatments regardless of the parameter considered.

\section{Table 2 - Variation of water content $(\%)$ and temperature $\left({ }^{\circ} \mathrm{C}\right)$ of substrates}

\begin{tabular}{lcccc} 
Variables & Chicken droppings & $\begin{array}{c}\text { Chicken droppings } \\
+ \text { blood }\end{array}$ & Pig slurry & Pig slurry +blood \\
\hline Water content & $46.18 \pm 29.13$ & $51.04 \pm 15.65$ & $68.40 \pm 1.84^{\mathrm{a}}$ & $87.47 \pm 4.49 \mathrm{~b}$ \\
Average temperature at 8 a.m. & $20.03 \pm 1.56$ & $20.54 \pm 1.72$ & $20.23 \pm 1.84$ & $24.75 \pm 3.47$ \\
Average temperature at 12 a.m. & $28.28 \pm 3.43$ & $27.82 \pm 3.74$ & $27.15 \pm 2.87$ & - \\
\hline a, b: the means with the same superscripts on the same line are not significantly different (P>0.05) & & &
\end{tabular}

Table 3 - Production of maggots as affected by the substrate

\begin{tabular}{|c|c|c|c|c|c|c|c|}
\hline \multirow{2}{*}{\multicolumn{2}{|c|}{ Biomass (g) }} & \multicolumn{4}{|c|}{ Substrates } & \multirow[b]{2}{*}{ MSD } & \multirow[b]{2}{*}{ P-value } \\
\hline & & Pig slurry & Pig slurry & Chicken & Chicken & & \\
\hline \multirow{2}{*}{ Day 5} & Fresh biomass & $131.25^{c}$ & $246.75^{d}$ & $6.67^{a}$ & $47^{b}$ & 26.02 & 0.001 \\
\hline & Dry biomass & $34^{c}$ & $59.25^{d}$ & $1.25^{a}$ & $16.50^{b}$ & 6.11 & 0.001 \\
\hline \multirow{2}{*}{ Day 10} & Fresh biomass & $28.75^{\mathrm{ab}}$ & $19.50^{a}$ & $26.25^{\mathrm{ab}}$ & $60.75^{b}$ & 5.60 & 0.022 \\
\hline & Dry biomass & $10.75^{a}$ & $\mathrm{Nd}$ & $12.25^{a}$ & $28^{b}$ & 2.90 & 0.001 \\
\hline
\end{tabular}

Table 4 - Nutritive value of maggots as affected by the substrate

\begin{tabular}{|c|c|c|c|c|}
\hline \multirow[b]{2}{*}{ Nutrients } & \multicolumn{4}{|c|}{ Substrates } \\
\hline & $\begin{array}{l}\text { Chicken } \\
\text { droppings }\end{array}$ & $\begin{array}{l}\text { Chicken droppings } \\
+ \text { blood }\end{array}$ & Pig slurry & $\begin{array}{l}\text { Pig slurry } \\
\text { + blood }\end{array}$ \\
\hline Crude protein (\%DM) & 41.01 & 50.85 & 57.14 & 54.41 \\
\hline Ash (\%DM) & 8.26 & 7.92 & 7.31 & 7.82 \\
\hline Potassium (g/kg) & 0.924 & 0.971 & 0.924 & 0.833 \\
\hline Sodium (g/kg) & 0.055 & 0.057 & 0.055 & 0.055 \\
\hline Phosphorus (g/kg) & 5.251 & 5.554 & 5.327 & 5.478 \\
\hline Calcium (g/kg) & 3.920 & 2.800 & 1.920 & 2.560 \\
\hline Magnesium (g/kg) & 7.047 & 7.793 & 7.928 & 7.651 \\
\hline Iron (mg/kg) & 0.306 & 0.306 & 0.306 & 0.281 \\
\hline
\end{tabular}


Table 5 - Variation of chick's performances and cost of production as affected by the treatments

\begin{tabular}{|c|c|c|c|c|c|}
\hline \multirow{2}{*}{$\begin{array}{l}\text { Growth } \\
\text { Parameters }\end{array}$} & \multicolumn{4}{|c|}{ Dietary treatments } & \multirow{2}{*}{ P-value } \\
\hline & TO & FM & BM & MA & \\
\hline Feed intake (g) & $1480.66 \pm 55.36$ & $1579.02 \pm 58.24$ & $1482.59 \pm 35.61$ & $1503.23 \pm 62.27$ & 0.076 \\
\hline Live weight (g) & $912.03 \pm 38.26 a$ & $935.90 \pm 18.41^{a}$ & $856.92 \pm 28.47^{b}$ & $895.97 \pm 4.02^{\mathrm{ab}}$ & 0.007 \\
\hline Weight gain (g) & $884.47 \pm 43.24^{\mathrm{ab}}$ & $911.87 \pm 15.74^{a}$ & $836.73 \pm 8.62^{c}$ & $857.06 \pm 4.02^{b c}$ & 0.004 \\
\hline Feed/weight ratio & $1.78 \pm 0.08^{a}$ & $1.64 \pm 0.05^{b}$ & $1.76 \pm 0.07^{a}$ & $1.72 \pm 0.04^{a b}$ & 0.047 \\
\hline Cost Kg/LW & $441.47 \pm 20.34^{a}$ & $393.95 \pm 13.70^{b}$ & $407.05 \pm 16.50^{b}$ & $409.98 \pm 10.25^{b}$ & 0.007 \\
\hline
\end{tabular}

Table 6 - Development of the regulatory and digestive organs of chicks as affected by treatments

\begin{tabular}{|c|c|c|c|c|c|}
\hline \multirow{2}{*}{ Organs } & \multicolumn{4}{|c|}{ Dietary treatments } & \multirow{2}{*}{$\begin{array}{c}\mathrm{P}- \\
\text { value }\end{array}$} \\
\hline & TO & FM & BM & MA & \\
\hline \multicolumn{6}{|l|}{ Regulatory organs(\% LW) } \\
\hline Kidney & $0.690 \pm 0.10$ & $0.742 \pm 0.07$ & $0.692 \pm 0.12$ & $0.558 \pm 0.26$ & 0.427 \\
\hline Liver & $2.14 \pm 0.19$ & $2.19 \pm 0.35$ & $2.22 \pm 0.21$ & $2.51 \pm 0.69$ & 0.311 \\
\hline \multicolumn{6}{|l|}{ Digestive organs } \\
\hline Live weight (\% LW) & $4.59 \pm 0.75$ & $5.82 \pm 0.97$ & $4.88 \pm 0.76$ & $5.00 \pm 1.19$ & 0.078 \\
\hline Intestinal length (cm) & $175.62 \pm 19.50$ & $186.00 \pm 19.47$ & $173.37 \pm 11.19$ & $172.12 \pm 14.99$ & 0.347 \\
\hline Intestinal density $(\mathrm{g} / \mathrm{cm})$ & $0.026 \pm 0.003$ & $0.031 \pm 0.004$ & $0.028 \pm 0.004$ & $0.028 \pm 0.005$ & 0.159 \\
\hline Bursa of Fabricius (g) & $0.690 \pm 0.16$ & $0.742 \pm 0.20$ & $0.692 \pm 0.14$ & $0.558 \pm 0.18$ & 0.215 \\
\hline
\end{tabular}

T0: Ration without animal meal; FM: Ration containing 5\% fishmeal; BM: Ration containing 5\% blood meal; MA: Ration containing 5\% maggot meal.

\section{DISCUSSION}

The result of the present study confirms the observations of many others authors (Mensah et al., 2007; Beskin et al., 2018) according to which fly larvae can be produced in various substrates available locally and unsolicited by humans. The larval stage is a very important stage of development in livestock feed because the larvae are rich in nutrients such as proteins, fats and minerals and is easily digestible by the animal. Regardless of the type of substrate used, high productivity of fly larvae was recorded on the $5^{\text {th }}$ day after seeding. The decrease observed in all substrates on the $10^{\text {th }}$ day can be explained by a low availability of organic matter which decreases as the maggots develop. Between the $10^{\text {th }}$ and the $15^{\text {th }}$ day, a transformation of the larvae into pupae is observed. This result confirms the findings of Hardouin et al. (2000) who reported that between 5 and 14 days of feeding, maggots enter the cocoon phase (mutation phase) during which they no longer feed and bury themselves in the substrate a few inches away until an adult fly has developed. This stage no longer contains the nutrients and according to Hardouin et al. (2000) and Hardouin and Mahoux (2003), the pupae are protected by a rigid envelope consisting essentially of keratin, the digestibility of which is greatly reduced in animals, although it is also a nitrogen product. Akilimali et al. (2019) also reported that it is important to determine the range of recommendable days to obtain the maximum number of larvae and the minimum number of pupae since it is preferable that farm animals receive the fewer pupas possible. Whatever the explanation, prolonging the rearing of maggots beyond the $15^{\text {th }}$ day would have no justification.

Regardless of the humidity level and with substrates enriched or not with blood, no significant difference $(P>0.05)$ was recorded between the substrates for the variation of temperature of the substrates. The temperature varied between 25 and $36^{\circ} \mathrm{C}$ during the day, with a humidity rate varying between 70 and $76 \%$ and 82 to $84 \%$ for the pig slurry and the chicken droppings respectively. These observations confirm those of Diener et al. (2009) who reported that fly eggs need a lot of humidity and the development of these larvae requires very high relative humidity. In addition, Keiding (1986) reported that the length of the house fly's reproductive cycle is a function of temperature and that the percentage of eggs hatched is maximum between 15 and $40^{\circ} \mathrm{C}$. Below $8^{\circ} \mathrm{C}$ and above $42^{\circ} \mathrm{C}$, all eggs die before hatching and the most favorable temperature for larval development is $35^{\circ} \mathrm{C}$.

Proximate analyzes of the maggot produced in the present study revealed high levels of protein and minerals. These results are in agreement with the findings of Bouafou et al. (2008) and Barragan-Fonseca et al. (2018) who reported that maggot meal has protein content comparable to that of animal meal. The present results showed that maggots are less rich in minerals such as potassium, sodium and iron compared to other animal meal. Dashefsky et al. (1796) reported that housefly pupae meal contained sufficient phosphorus, which is highly bioavailable in poultry. This finding may suggest that the mineral content of the fly depends on its stage of development.

The ANOVA revealed no significant difference $(P>0.05)$ between all batches of chicks for feed intake. However, the chicks fed on maggot meal tend to consume more than chicks fed on the control ration without animal meal. This result 
confirms the findings of Loa (2000) who revealed that maggots are a preferred food for poultry compared to cereals. Similarly, the present result agree with the findings of Bouafou et al. (2008 and 2011) who reported that, rats fed on dried maggot meal have zootechnical performances comparable to rats fed on fish and meat meal with regard to feed intake, coefficients of feed and protein efficiency, apparent and real digestibility.

Chicks fed on maggot meal recorded a body weight comparable $(P>0.05)$ to that of all other batches of chicks. This result corroborates those of Bouafou et al. (2011) who reported that the incorporation of maggot meal in the feed is very suitable for optimal growth of young rats. Interesting results have also been reported by Malekani (2001), Cicogna (2000), De Marco et al. (2015), and by Mensah and Ekue (2002) who have successfully incorporated maggots into the feed of pets and farm animals. Likewise, Mensah et al. (2007), with a ration containing $11 \%$ maggot meal, crushed corn kernels, red oil, onion, Moringa oleifera, table salt and shell oyster ash, recorded interesting results in growth rate of Muscovy ducklings (1.3 kg at 8 weeks of age) and reduction in their mortality rate (less than 6\%). Thus, this feed, coupled with good breeding behavior, ensures good start of day-old ducklings. This result can be explained by the fact that the protein content of maggot flour is comparable to that of animal meal as previously reported by Bouafou et al. (2008). In the same way, Sonaiya and Swan (2004) reported that maggots are potential protein sources that can be used as a supplement to low-protein or low-quality diets such as cassava and sweet potato.

The cumulative feed conversion ratio was significantly $(P<0.05)$ lower with the ration containing fishmeal. While, chicks fed on maggot meal were comparable $(P>0.05)$ to all other groups of chicks including the control, for this parameter. The present result contradicted the findings of Bouafou et al. (2008) who reported that rats fed on maggot meal based diet generally had the best zootechnical performance than those fed on fish or meat meal.

ANOVA result did not reveal any significant difference $(P>0.05)$ between treatments groups for the development of digestive organs regardless of the parameter considered. However, there is a downward trend in the relative kidney weight, bowel length, and the relative weight of the bursa of Fabricius, but with an upward trend in the relative weight of the liver with maggot meal compared to all other groups. This result corroborates the findings of Bouafou et al. (2011) who concluded from a study on the biometrics of growing rats fed on maggot meal based diet at a rate of $10 \%$, observed a decrease in the weight of their kidneys of $6.60 \%$ and an increase in liver weight of $10.60 \%$ compared to controls.

With maggot meal, the cost of production of $\mathrm{kg}$ live body weight was comparable to rations containing fish and blood meals. These results confirm those of Hardouin et al. (2000), Téguia et al. (2002), de Hardouin and Mahoux (2003) who concluded that, from a technical and economic point of view, maggot meal could partly replace fish meal in monogastric feed, such as hens, guinea fowl, even pigs and fish. Similarly, Bouafou et al. (2006) reiterated that this practice makes it possible to improve at very low cost the performance of animals fed on unbalanced diet, as is often the case in family animals breeding.

\section{CONCLUSION}

The productivity of housefly larvae varies significantly with the type of substrate used. Pig slurry enriched with fresh blood has a higher and greater productivity over time. The most suitable period for harvesting maggots is between the $5^{\text {th }}$ and $10^{\text {th }}$ day, whatever the substrate. The temperature of the substrate for good productivity is above $25^{\circ} \mathrm{C}$. Whatever the type of substrate, maggots are appreciable source of protein and minerals, particularly calcium and magnesium. Maggot meal can be used up to $5 \%$ in feed for the production of chicks at a lower cost, without abnormalities in the regulatory organs of the broiler chick at the starter phase.

\section{DECLARATIONS}

\section{Authors' contribution}

All authors were contributed equally.

Conflict of interests

The authors declare that they have no competing interests.

\section{REFERENCES}

Akilimali IJ, Shukuru WD, Muzee KL, Ntagereka PB, and Baluku BJP (2019). Production trial and chemical composition of maggots obtained from local substrates in South Kivu (DRC). Journal of Applied Biosciences 142: 14529 - 14539. Link: https://dx.doi.org/10.4314/jab.v142i1.7

AOAC (1990). Association of Official Analytical Chemist. Official method of analysis, 15 th Edition. Washington D.C. pp. 10.

Balengola I (2012). Comparative study of maggot production in Kinshasa (case of brewer's spent grain, pork stomach content, pig manure and chicken manure), TFE in Zootechnic, Faculty of Agronomic Sciences, Uniki. 25p. Link: http://www.congovirtuel.com/page_rapport_travaux/tfc_unikin/tfc_mangunga.pdf

Baragan-Fonseca KB, Dicke M and Van Loon JJA (2018). Influence of larval density and dietary nutrient concentration on performance, body protein and fat contents of black soldier fly larvae (Hermetia illucens). Entomologist Experimentalis and Applicata, 166 (9): $761-770$. DOI: https://doi.org/10.1111/eea.12716

Beskin KV, Holcomb CD, Cammack JA, Crippen TL, Knap AH, Sweet ST and Tomberlin JK (2018). Larval digestion of different manure types by the black soldier fly (Diptera: Stratiomyidae) impacts associated volatile emissions. Waste Management, 75: 213-220. Dol: https://doi.org/10.1016/j.wasman.2018.01.019 
Biasato I, Renna M, Gai F, Dabbou S, Meneguz M, Perona G, Martinez S, Lajusticia AC, Bergagna S, and Sardi L (2019). Partially defatted black soldier fly larva meal inclusion in piglet diets: Effects on the growth performance, nutrient digestibility, blood profile, gut morphology and histological feature. Journal of Animal Science and Biotechnology, 10: Article number 12. D0I: https://doi.org/10.1186/s40104-019-0325$\underline{\mathbf{x}}$

Bouafou KGM, Konan BA, Méité A, Kouamé KG and Kati-Coulibaly S (2011). Substitution of fishmeal for dried maggot meal in the diet of growing rats: pathological risks. Journal of Applied Biosciences, 5:1298-1303. Link: http://www.m.elewa.org/JABS/2011/48/2.pdf

Bouafou KGM, Kouamé KG, Amoikon EK and Offoumou AM (2006). Potentials for the production of maggots on by-products in Côte d'Ivoire. Tropicultura, 24(3), 157-161. Link: http://www.tropicultura.org/text/v24n3/157.pdf

Bouafou KGM, Zannou-Thoko V, Konan BAE and Kouamé KG (2008). Study of the nutritional value of dried maggot flour in growing rats. Ivorian Journal of Science and Technology, 12(2008): 215-225. Link: https://revist.net/REVIST_12/REVIST_12_15.pdf

Charlton AJ, Dickinson M, Wakefield ME, Fitches E, Kenis M, Han R and Bruggeman G (2015). Exploring the chemical safety of fly larvae as a source of protein for animal feed. Journal of Insects as Food and Feed, 1(1):7-16. DOI: https://doi.org/10.3920/JIFF2014.0020

Cicogna (2000). Technical guide for breeding $n^{\circ} 4$ on guinea pigs [On line]. Bureau for the Exchange and Distribution of Mini-Breeding Information (B.E.D.I.M.), ed. J. Hardouin, BEDIM. 8p. https://docplayer.fr/151485750-Guide-technique-d-elevage-n-4-sur-les-cobayesdecembre-2000.html

Dashefsky HS, Anderson DL, Tobin EN and Peters TM (1976). Face fly pupae: a potential food supplement for poultry. Environmental Entomology, 5(4): 680-682. DOI: https://doi.org/10.1093/ee/5.4.680

De Smet J, Wynants E, Cos P, Van Campenhout L (2018). Microbial community dynamics during rearing of black soldier fly larvae (Hermetia illucens) and impact on exploitation potential. Applied and Environmental Microbiology, 48(9):02722-17. DOI: https://doi.org/10.1128/AEM.02722-17

Diener S, Zurbrugg C, and Tockner K (2009). Conversion of organic material by black soldier fly larvae: Establishing optimal feeding rates. Waste Management Resources, 27(6):603-610. DOI: https://doi.org/10.1177\%2F0734242X09103838

Finke M (2013).Complete nutrient content of four species of feeder insects. Zoo Biology, 32(1):27-36. DOI: https://doi.org/10.1002/zoo.21012

Hardouin J and Mahoux G (2003). Zootechny of insects - Breeding and use for the benefit of man and certain animals. Bureau for the Exchange and Distribution of Information inter https://www.scirp.org/(S(i43dyn45teexjx455qlt3d2q))/reference/ReferencesPapers.aspx?ReferenceID=2083388

Hardouin J, Dongmo T, Ekoue SK, LOA C, Malekani M and Malukisa M (2000). Technical guide $n^{\circ} 7$ on maggots [On line]. Bureau for the Exchange and Distribution of Mini-Livestock Information (BEDIM), ed. Hardouin J, BEDIM, 8p. [02/28/2006] Link: www.bib.fsagx.ac.be/bedim/production/

Hatab MH, Ibrahim NS, Sayed WA, and Sabic EM. (2020). Potential value of using insect meal as an alternative protein source for Japanese quail diet. Brazilian Journal of Poultry Science, 22(1):1-10. DOI: https://doi.org/10.1590/1806-9061-2017-0700

Keiding J (1986). The house fly. Training and Information Guide, Vector Control Series. WHO Ed., 60 pp. Link: https://apps.who.int/iris/handle/10665/60126

Loa C (2000). Production and controlled use of maggots. Tropicultura, 18(4): 215-219. Link: http://www.tropicultura.org/text/v18n4/215.pdf

Malekani JM (2001). Technical breeding guide No.8 on cricetomas [On line]. Bureau for the exchange and distribution of information on minibreeding (B.E.D.I.M.) ed. J. Hardouin, BEDIM, 8 pages. [02/28/2006] Link: www.bib.fsagx.ac.be/bedim/production/guide/pdf/8.pdf

Mensah GA and Ekue MRM (2002). Rearing Technical Guide No1 on Grasscutters.

Mensah GA, Pomalegni SCB, Koudjou AL, Cakpovi JCG, Adjahoutonon KYKB and Agoundo A (2007). Maggot meal, a well-valued source of protein in duck feed, Workshop: Natural and Agronomic Sciences, UAC of sciences and cultures in Abomey-calavi (Benin). Link: http://www.slire.net/download/565/farine_d_asticot_de_mouche_une_source_de_prot_ines_bien_valoris_e_dans_I_alimentation_des_ca nards de barbarie.pdf

Sonaiya EB and Swan SEJ (2004). Family Poultry Production, Animal Production and Health, Technical Manual, Department of Poultry, F.A.0, Rome. https://www.lavoisier.fr/livre/productions-animales/production-en-aviculture-familiale-un-manuel-technique/sonaiya/descriptif9789252050827

Téguia A, Mpoamé M and Okourou Mba JA (2002). The production performance of broiler birds as affected by the replacement of fish meal by maggot meal in the starter and finisher diets. Tropicultura, 20 (4): 187-192. Link: http://www.tropicultura.org/text/v20n4/187.pdf

Tshinyama NA (2009). Promotion of family breeding of local chickens through the rational use of feed made from local ingredients and available in Kinshasa (DRC). Complementary Master in Resource Management, Animal and Plant Development in Tropical Environments. University of Liège (ULg-Fusagx), Faculty of Veterinary Medicine. Liège, Belgium. 